\section{Still Charging: The Growth of Credit Card Debt between 1992 and 1995}

\section{Peter S. Yoo}

thecrir etween the end of the last recession in the first quarter of 1991 and the second quarter of 1997, consumer revolving credit outstanding, which includes consumer credit card debt, more than doubled-from $\$ 247$ billion to $\$ 514$ billion. The rapid rise of consumer debt, especially credit card debt, generated much discussion about its cause, sustainability, and implication despite the fact that credit card debt is a small part of a household's total indebtedness. ${ }^{1}$ The discussion often referred to aggregate data, such as consumer revolving credit outstanding, but such data fail to provide details that are necessary for a clear understanding of the factors that contributed to the growth of consumer credit card debt.

I therefore undertook a simple study using household data to examine the components that contributed to the growth of total credit card debt. The analysis, Yoo (1997), showed that increases in average balances accounted for most of the growth of credit card debt. It also indicated that lower-income households- those in the bottom half of the income distributionincreased their credit card ownership rate and average credit card balances faster than the population, but upper-income households were responsible for most of the rise in total credit card debt. Unfortunately, the data used in the study - the Survey of Consumer Finances conducted in 1983, 1989, and 1992-did not cover most of the period since the end of the last recession.

The recent release of the 1995 survey provides an opportunity to update the analysis by using the new data to separate the growth of credit card debt between 1992 and 1995 into its two main components: an increase in the number of households with credit cards and an increase in the average bal ances on credit cards. As before, the analysis also separates the effects of lower- and upperincome households on the growth of credit card debt over that period. Finally, I compare the growth of credit card debt between 1992 and 1995 to its growth during the other intersurvey years. Such comparisons may identify characteristics that have affected the recent growth of credit card debt that were not previously significant.

\section{SURVEY OF CONSUMER FINANCE}

Every three years, the Federal Reserve, with the assistance of other agencies and organizations, conducts the Surveys of Consumer Finances (SCF) to obtain detailed information about households' assets, liabilities, incomes, and use of financial institutions and instruments such as credit cards. ${ }^{2}$ Each survey uses a random sample of U.S. households with an oversample of high-income and highweal th households to obtain a detailed, comprehensive, and representative picture of U.S. households. ${ }^{3}$ The oversampling is necessary because income and wealth are concentrated among a small number of households, so a random sample of the population will miss too many dollars. The 1995 survey sampled 4,299 households.

For this study, I split the households into income deciles to examine the relationship between household income and credit cards. Parsing households in such a manner
${ }^{1}$ Kennickell, et al. (1997) found that credit card debt accounted for a very small fraction of a household's total indebtedness- 2.3 percent in 1989, 2.8 percent in 1992 , and 3.7 percent in 1995.

${ }^{2}$ Avery and Elliehausen (1986), Avery, et al. (1984a, 1984b), Kennickell and Shack-Marquez (1992), Kennickell and StarrMcCluer (1994), and Kennickell, et al. (1997) provide more details of the surveys.

${ }^{3}$ Antoniewiz (1996) and Avery, et al. (1988) find that the information in the survey corresponds closely to the findings of other surveys and aggregate estimates. 


\section{Table 1}

Income Deciles and Number of Households within Each Decile

\begin{tabular}{|c|c|c|c|c|}
\hline Percentile & 1983 & 1989 & 1992 & 1995 \\
\hline $0-10$ & $\begin{array}{c}(-24,5) \\
388\end{array}$ & $\begin{array}{l}(0,6) \\
1,131\end{array}$ & $\begin{array}{c}(-1,000,7) \\
1,419\end{array}$ & $\begin{array}{c}(-1,000,7) \\
1,568\end{array}$ \\
\hline $10-20$ & $\begin{array}{l}(5,9) \\
376\end{array}$ & $\begin{array}{l}(6,10) \\
1,167\end{array}$ & $\begin{array}{l}(7,11) \\
1,317\end{array}$ & $\begin{array}{l}(7,12) \\
1,439\end{array}$ \\
\hline $20-30$ & $\begin{array}{l}(9,12) \\
375\end{array}$ & $\begin{array}{c}(10,14) \\
1,088\end{array}$ & $\begin{array}{c}(11,15) \\
1,359\end{array}$ & $\begin{array}{c}(12,17) \\
1,493\end{array}$ \\
\hline $30-40$ & $\begin{array}{c}(12,15) \\
363\end{array}$ & $\begin{array}{c}(14,20) \\
1,156\end{array}$ & $\begin{array}{c}(15,20) \\
1,432\end{array}$ & $\begin{array}{c}(17,22) \\
1,554\end{array}$ \\
\hline $40-50$ & $\begin{array}{c}(15,20) \\
371\end{array}$ & $\begin{array}{c}(20,24) \\
1,142\end{array}$ & $\begin{array}{c}(20,26) \\
1,456\end{array}$ & $\begin{array}{c}(22,30) \\
1,597\end{array}$ \\
\hline $50-60$ & $\begin{array}{c}(20,24) \\
367\end{array}$ & $\begin{array}{c}(24,30) \\
1,193\end{array}$ & $\begin{array}{c}(26,33) \\
1,456\end{array}$ & $\begin{array}{c}(30,36) \\
1,687\end{array}$ \\
\hline $60-70$ & $\begin{array}{c}(24,30) \\
367\end{array}$ & $\begin{array}{c}(30,38) \\
1,219\end{array}$ & $\begin{array}{c}(33,41) \\
1,468\end{array}$ & $\begin{array}{c}(36,45) \\
1,734\end{array}$ \\
\hline $70-80$ & $\begin{array}{c}(30,37) \\
373\end{array}$ & $\begin{array}{c}(38,49) \\
1,328\end{array}$ & $\begin{array}{c}(41,53) \\
1,561\end{array}$ & $\begin{array}{c}(45,59) \\
1,856\end{array}$ \\
\hline $80-90$ & $\begin{array}{c}(37,50) \\
358\end{array}$ & $\begin{array}{c}(49,66) \\
1,504\end{array}$ & $\begin{array}{c}(53,76) \\
1,904\end{array}$ & $\begin{array}{c}(59,80) \\
2,134\end{array}$ \\
\hline $90-100$ & $\begin{array}{c}(50,3,426) \\
774\end{array}$ & $\begin{array}{c}(66,99,491) \\
4,796\end{array}$ & $\begin{array}{c}(76,65,300) \\
6,136\end{array}$ & $\begin{array}{c}(80,99,730) \\
6,441\end{array}$ \\
\hline Total Survey & $\begin{array}{c}(-24,3,426) \\
4,103\end{array}$ & $\begin{array}{c}(0,99,491) \\
15,715\end{array}$ & $\begin{array}{c}(-1,000,65,300) \\
19,500\end{array}$ & $\begin{array}{c}(-1,000,99,730) \\
21,495\end{array}$ \\
\hline
\end{tabular}

NOTES: Ranges are shown in thousands of dollars. Number of observations in each cell may not equal the total observations because some fall within more than one cell.

creates ranges that are invariant to trends that affect the overall economy, so changes in household income that arise from inflation or real economic growth do not affect the position of households within the deciles. Separating households by deciles also creates partitions that represent 10 percent of all households, thereby eliminating excessive concentration of the population within any particular range. Table 1 shows the ranges for the income deciles and the number of households within each decile for the 1995 SCF. ${ }^{4}$ The table also shows the ranges from the three previous surveys as reference. The larger sample sizes for the higher income categories reflects the oversampling of the high-income and high-wealth households.

\section{CHANGES IN THE NUMBER OF HOUSEHOLDS WITH CREDIT CARDS}

Two factors account for the growth of aggregate credit card debt: more credit cards and higher balances per credit card. This section examines how the number and distribution of credit card ownership changed between 1992 and 1995. A credit card as defined in this study falls into one of five categories identified in the survey: bank-type 


\section{Table 2}

Percent of Households with Credit Cards, by Income Percentiles

\begin{tabular}{|c|c|c|c|c|}
\hline Percentile & 1983 & 1989 & 1992 & 1995 \\
\hline $0-10$ & $\begin{array}{c}19 \\
(15,23)\end{array}$ & $\begin{array}{c}21 \\
(17,23)\end{array}$ & $\begin{array}{c}26 \\
(24,29)\end{array}$ & $\begin{array}{c}32 \\
(30,34)\end{array}$ \\
\hline $10-20$ & $\begin{array}{c}33 \\
(28,39)\end{array}$ & $\begin{array}{c}39 \\
(37,43)\end{array}$ & $\begin{array}{c}42 \\
(39,45)\end{array}$ & $\begin{array}{c}44 \\
(42,48)\end{array}$ \\
\hline $20-30$ & $\begin{array}{c}47 \\
(42,54)\end{array}$ & $\begin{array}{c}54 \\
(50,58)\end{array}$ & $\begin{array}{c}66 \\
(64,69)\end{array}$ & $\begin{array}{c}63 \\
(60,66)\end{array}$ \\
\hline $30-40$ & $\begin{array}{c}57 \\
(51,62)\end{array}$ & $\begin{array}{c}64 \\
(59,67)\end{array}$ & $\begin{array}{c}68 \\
(65,70)\end{array}$ & $\begin{array}{c}70 \\
(67,72)\end{array}$ \\
\hline $40-50$ & $\begin{array}{c}66 \\
(61,72)\end{array}$ & $\begin{array}{c}72 \\
(69,76)\end{array}$ & $\begin{array}{c}67 \\
(64,70)\end{array}$ & $\begin{array}{c}74 \\
(71,76)\end{array}$ \\
\hline $50-60$ & $\begin{array}{c}74 \\
(69,79)\end{array}$ & $\begin{array}{c}84 \\
(81,86)\end{array}$ & $\begin{array}{c}82 \\
(80,84)\end{array}$ & $\begin{array}{c}84 \\
(82,86)\end{array}$ \\
\hline $60-70$ & $\begin{array}{c}82 \\
(77,85)\end{array}$ & $\begin{array}{c}87 \\
(86,90)\end{array}$ & $\begin{array}{c}88 \\
(86,90)\end{array}$ & $\begin{array}{c}90 \\
(87,91)\end{array}$ \\
\hline $70-80$ & $\begin{array}{c}88 \\
(84,91)\end{array}$ & $\begin{array}{c}91 \\
(90,93)\end{array}$ & $\begin{array}{c}90 \\
(88,91)\end{array}$ & $\begin{array}{c}93 \\
(92,95)\end{array}$ \\
\hline $80-90$ & $\begin{array}{c}91 \\
(88,94)\end{array}$ & $\begin{array}{c}94 \\
(92,95)\end{array}$ & $\begin{array}{c}94 \\
(92,95)\end{array}$ & $\begin{array}{c}97 \\
(96,98)\end{array}$ \\
\hline $90-100$ & $\begin{array}{c}97 \\
(95,98)\end{array}$ & $\begin{array}{c}98 \\
(97,99)\end{array}$ & $\begin{array}{c}96 \\
(95,97)\end{array}$ & $\begin{array}{c}99 \\
(98,99)\end{array}$ \\
\hline Total Survey & $\begin{array}{c}64 \\
(64,67)\end{array}$ & $\begin{array}{c}70 \\
(69,71)\end{array}$ & $\begin{array}{c}72 \\
(71,73)\end{array}$ & $\begin{array}{c}75 \\
(74,75)\end{array}$ \\
\hline
\end{tabular}

NOTE: Ninety-five percent confidence intervals from bootstrapping are shown in parentheses.

(Visa, Mastercard, etc.), gasoline company, general purpose (American Express, Diner's Club, etc.), store and other (rental car, airlines, etc.). I also do not distinguish among households with multiple credit cards because an additional card is analogous to an increase in the credit limit of an existing card.

As Table 2 shows, three-quarters of all American households had at least one credit card in 1995. This level is three percentage points higher than in 1992, and it represents a continuation of a trend that is evident in the data from the earlier surveys. ${ }^{5}$ Nearly all income groups shared in this increase from the 1992 ownership rates, and the confidence intervals of the estimates from 1992 and 1995 suggest that half of the differences for each income category may be statistically significant. ${ }^{6}$ The data also suggest that these changes within each income decile are consistent with the pattern of increasing credit card ownership suggested by the earlier surveys. Lowerincome households were more likely to have a credit card in 1995 than in 1992, but the increase is not noticeably greater than it was between surveys for other years.

Table 2 also confirms that the likelihood of credit card ownership increased with income. In 1995, households in the highest income group were more than three times as likely to have a credit card as those in the lowest income group, and the fraction of

\footnotetext{
${ }^{5}$ Narrowing the focus of the analysis to bank-type credit cards does not alter the conclusions of this section nor of those that follow. Sixty-seven percent of all households had bank-type credit cards in 1995, and 62 percent of all households had them in 1992.

${ }^{6}$ I constructed the confidence interval using a bootstrap method. I drew 1,000 random samples with replacement from the original survey. I then estimated the fraction of the population that had credit cards for each new sample and calculated the 95 percent confidence interval from the bootstrapped estimates. The table does not strictly allow for hypothesis tests because the confidence intervals do not reflect any joint variation that may exist between estimates.
} 


\section{Table 3}

\section{Average Annual Growth Rates of Factors Affecting \\ Total Credit Card Debt (percent)}

\begin{tabular}{lcccc} 
Factor & $\mathbf{1 9 8 3 - 8 9}$ & $\mathbf{1 9 8 9 - 9 2}$ & $\mathbf{1 9 9 2 - 9 5}$ \\
\cline { 3 - 4 } \cline { 2 - 4 } Total cedit card debt & 17.2 & 9.8 & 12.2 \\
Number of households & 1.8 & 0.9 & 1.1 \\
Number of households with CC & 3.0 & 1.7 & 2.4 \\
of lower-income households & 3.6 & 3.6 & 2.8 \\
of upper-income households & 2.7 & 0.5 & 2.1 \\
Inflation (CPI) & 3.7 & 4.2 & 2.8 \\
Median household income & 3.5 & 2.7 & 4.9 \\
Average CC debt & 13.8 & 8.0 & 9.6 \\
of lower-income housseholds & 14.4 & 9.9 & 13.9 \\
of upper-income households & 13.7 & 7.9 & 8.1
\end{tabular}

households with credit cards rose with income. All but two comparisons of ownership rates between adjacent deciles appear to be statistically significant.

Surprisingly, lower-income households did not increase their ownership rates faster than upper-income households between 1992 and 1995. The fraction of upper-income households with credit cards rose from 90 percent in 1992 to 93 percent in 1995, whereas the figures for lower-income households increased from 54 percent to 57 percent. Although the two largest increases in ownership rates were among the lower-income households, the next three biggest increases occurred within upper-income household deciles. Despite the higher fraction of lowerincome households having credit cards and the general increase in the number of households between 1992 and 1995, the average annual growth rate of lower-income households with credit cards, shown in Table 3, was lower between 1992 and 1995 than during the other intersurvey years.

Although the fraction of households with credit cards grew for every income category, the increases were similar in magnitude, so the income distribution of credit cardholders barely changed between 1992 and 1995. Figure 1 shows the income distribution of households with credit cards from all four surveys. The positive slope of the lines illustrates the positive relationship between income and the likelihood of having a credit card; if credit card ownership and income were independent, the income distribution of households with credit cards would be uniform at 10 percent per decile. More importantly, the lines for 1992 and 1995 are nearly identical for the top half of the distribution, indicating that the relative importance of upper-income households among all households with credit cards did not change noticeably between the two years. In fact, the fraction of households with credit cards that were in the bottom half of the income distribution increased slightly from 37.5 percent in 1992 to 37.9 percent in $1995 .{ }^{7}$

\section{CHANGES IN CREDIT CARD BALANCES}

Aggregate credit card debt also increases if households carry larger balances. The SCF provides information about the size of each household's credit card debt after the most recent payment. This definition of credit card debt eliminates the balances of households who use their credit cards for convenience and pay their balances in full.

Data from the 1995 SCF suggest that the trends observed in my previous study continued through 1995. First, average credit card debt generally increased with income. As shown in Table 4, the average 
credit card indebtedness of the households in the highest income decile was nearly twice the average balances of those in the lowest decile. Second, average credit card debt continued to increase over time. The average balance for all households with credit cards increased at a 10 percent annual rate between 1992 and 1995; the average balances for most income groups grew at similar rates. Finally, lower-income households' average credit card debt increased more than that of upper-income households, 14 percent annual rate versus 8 percent annual rate between 1992 and 1995.

Recent concerns about the indebtedness of lower-income households notwithstanding, the increases in average balances for lowerincome households between 1992 and 1995

\section{Figure 1}

Income Distribution of Households with Credit Cards

Percent of All Households with Credit Cards

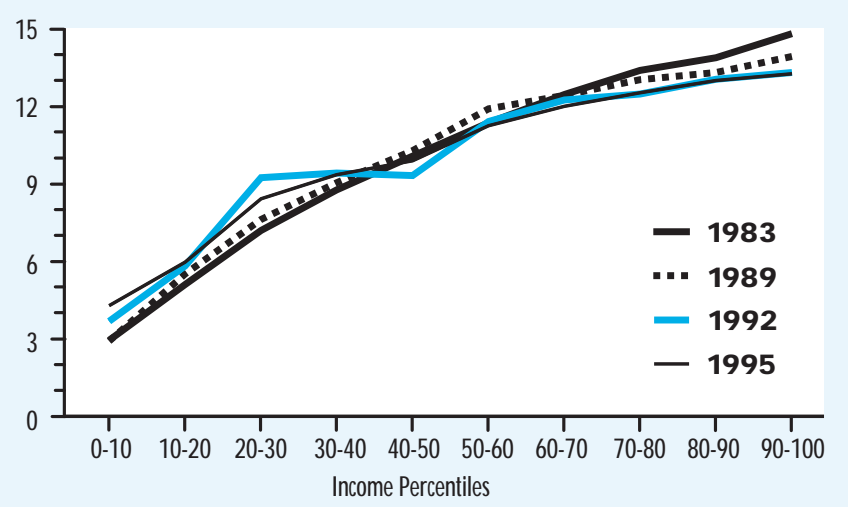

Table 4

Average Credit Card Balances, by Income Percentiles

\begin{tabular}{|c|c|c|c|c|}
\hline \multirow[b]{2}{*}{ Percentile } & \multirow[b]{2}{*}{1995} & \multicolumn{3}{|c|}{$\begin{array}{c}\text { Average Annual Growth Rates between } \\
\text { (percent) }\end{array}$} \\
\hline & & $1983-89$ & 1989.92 & $1992-95$ \\
\hline $0-10$ & $\begin{array}{c}1,358 \\
(1,000,1,753)\end{array}$ & -5 & 53 & 20 \\
\hline $10-20$ & $\begin{array}{c}1,267 \\
(898,1,461)\end{array}$ & 6 & 35 & 18 \\
\hline $20-30$ & $\begin{array}{c}1,253 \\
(1,114,1,523)\end{array}$ & 17 & 13 & 9 \\
\hline $30-40$ & $\begin{array}{c}1,312 \\
(1,198,1,482)\end{array}$ & 9 & 20 & 10 \\
\hline $40-50$ & $\begin{array}{c}1,704 \\
(1,537,1,885)\end{array}$ & 20 & -5 & 17 \\
\hline $50-60$ & $\begin{array}{c}1,723 \\
(1,517,1,897)\end{array}$ & 7 & 20 & 9 \\
\hline $60-70$ & $\begin{array}{c}1,525 \\
(1,353,1,750)\end{array}$ & 15 & 15 & -4 \\
\hline $70-80$ & $\begin{array}{c}1,945 \\
(1,795,2,119)\end{array}$ & 12 & 9 & 8 \\
\hline $80-90$ & $\begin{array}{c}2,136 \\
(1,915,2,341)\end{array}$ & 15 & 2 & 11 \\
\hline $90-100$ & $\begin{array}{c}2,551 \\
(2,282,2,823)\end{array}$ & 18 & 1 & 14 \\
\hline Total Survey & $\begin{array}{c}1,768 \\
(1,703,1,834)\end{array}$ & 14 & 8 & 10 \\
\hline
\end{tabular}

NOTES: Figures for 1995 are shown in dollars. Ninety-five percent confidence intervals from bootstrapping are shown in parentheses. 


\begin{tabular}{|c|c|c|c|c|}
\hline \multicolumn{5}{|c|}{ Median Credit Card Balances, by Income Percentiles } \\
\hline \multirow[b]{2}{*}{ Percentile } & \multirow[b]{2}{*}{1995} & \multicolumn{3}{|c|}{$\begin{array}{c}\text { Average Annual Growth Rates betwee } \\
\text { Surveys (percent) }\end{array}$} \\
\hline & & 1983.89 & 1989.92 & $1992-95$ \\
\hline $0-10$ & $\begin{array}{c}50 \\
(0,150)\end{array}$ & 0 & 0 & -37 \\
\hline $10-20$ & $\begin{array}{c}140 \\
(100,200)\end{array}$ & 0 & -100 & 0 \\
\hline $20-30$ & $\begin{array}{c}200 \\
(100,220)\end{array}$ & 0 & 0 & 0 \\
\hline $30-40$ & $\begin{array}{c}380 \\
(200,500)\end{array}$ & -100 & 0 & 18 \\
\hline $40-50$ & $\begin{array}{c}400 \\
(250,560)\end{array}$ & 7 & -10 & 26 \\
\hline $50-60$ & $\begin{array}{c}460 \\
(270,600)\end{array}$ & -2 & 42 & 5 \\
\hline $60-70$ & $\begin{array}{c}400 \\
(310,500)\end{array}$ & 12 & 10 & 0 \\
\hline $70-80$ & $\begin{array}{c}500 \\
(400,590)\end{array}$ & 7 & -6 & 26 \\
\hline $80-90$ & $\begin{array}{c}500 \\
(370,590)\end{array}$ & 22 & -24 & 36 \\
\hline 90-100 & $\begin{array}{c}0 \\
(0,0)\end{array}$ & 0 & 0 & 0 \\
\hline Total Survey & $\begin{array}{c}270 \\
(220,300)\end{array}$ & 7 & 8 & 12 \\
\hline
\end{tabular}

NOTES: Figures for 1995 are shown in dollars. Ninety-five percent confidence intervals from bootstrapping are shown in parentheses.

were smaller than the increases between 1989 and 1992. The average credit card balances for nearly all lower-income categories rose by a smaller percentage during the most recent intersurvey period than during the previous one; the one exception was the fifth decilehouseholds with incomes between $\$ 22,000$ and $\$ 30,000$.

Median estimates of credit card balances, shown in Table 5, also show similar patterns, although they show that many households carried little, if any, credit card debt in 1995. Estimates from the recent survey indicate that nearly half of all households with credit cards did not carry a balance, shown in Table 6 .
M oreover, nearly two-thirds of all households carrying credit card debt were upper-income households.

The increase in average credit card debt of lower-income households, coupled with the slight increase in the relative number of lower-income households with credit cards, shifted the income distribution of all credit card debt toward the bottom half in 1995, as shown in Figure 2. The share of credit card debt held by households in all but one lower-income group rose between 1992 and 1995, so the lower-income households' share of all credit card debt rose from 27 percent in 1992 to 30 percent in 1995. 


\section{Table 6}

Percent of Households Carrying Credit Card Balances, by Income Percentiles

\begin{tabular}{|c|c|c|c|c|}
\hline Percentile & 1983 & 1989 & 1992 & 1995 \\
\hline $0-10$ & $\begin{array}{c}46 \\
(34,57)\end{array}$ & $\begin{array}{c}46 \\
(42,56)\end{array}$ & $\begin{array}{c}66 \\
(60,71)\end{array}$ & $\begin{array}{c}53 \\
(48,58)\end{array}$ \\
\hline $10-20$ & $\begin{array}{c}46 \\
(37,56)\end{array}$ & $\begin{array}{c}54 \\
(47,58)\end{array}$ & $\begin{array}{c}43 \\
(39,48)\end{array}$ & $\begin{array}{c}60 \\
(56,64)\end{array}$ \\
\hline $20-30$ & $\begin{array}{c}48 \\
(41,57)\end{array}$ & $\begin{array}{c}48 \\
(43,52)\end{array}$ & $\begin{array}{c}60 \\
(56,63)\end{array}$ & $\begin{array}{c}58 \\
(53,60)\end{array}$ \\
\hline $30-40$ & $\begin{array}{c}52 \\
(44,59)\end{array}$ & $\begin{array}{c}46 \\
(41,50)\end{array}$ & $\begin{array}{c}57 \\
(54,61)\end{array}$ & $\begin{array}{c}61 \\
(58,64)\end{array}$ \\
\hline $40-50$ & $\begin{array}{c}63 \\
(57,69)\end{array}$ & $\begin{array}{c}66 \\
(61,70)\end{array}$ & $\begin{array}{c}63 \\
(59,66)\end{array}$ & $\begin{array}{c}63 \\
(60,66)\end{array}$ \\
\hline $50-60$ & $\begin{array}{c}64 \\
(57,70)\end{array}$ & $\begin{array}{c}60 \\
(56,64)\end{array}$ & $\begin{array}{c}67 \\
(64,70)\end{array}$ & $\begin{array}{c}64 \\
(61,66)\end{array}$ \\
\hline $60-70$ & $\begin{array}{c}63 \\
(58,69)\end{array}$ & $\begin{array}{c}61 \\
(58,66)\end{array}$ & $\begin{array}{c}63 \\
(60,67)\end{array}$ & $\begin{array}{c}61 \\
(58,64)\end{array}$ \\
\hline $70-80$ & $\begin{array}{c}64 \\
(58,69)\end{array}$ & $\begin{array}{c}63 \\
(59,67)\end{array}$ & $\begin{array}{c}59 \\
(55,61)\end{array}$ & $\begin{array}{c}65 \\
(63,68)\end{array}$ \\
\hline $80-90$ & $\begin{array}{c}60 \\
(53,64)\end{array}$ & $\begin{array}{c}66 \\
(63,70)\end{array}$ & $\begin{array}{c}55 \\
(53,58)\end{array}$ & $\begin{array}{c}61 \\
(59,64)\end{array}$ \\
\hline $90-100$ & $\begin{array}{c}44 \\
(40,51)\end{array}$ & $\begin{array}{c}47 \\
(44,50)\end{array}$ & $\begin{array}{c}38 \\
(36,41)\end{array}$ & $\begin{array}{c}47 \\
(44,49)\end{array}$ \\
\hline Total Survey & $\begin{array}{c}57 \\
(55,59)\end{array}$ & $\begin{array}{c}57 \\
(56,58)\end{array}$ & $\begin{array}{c}57 \\
(56,58)\end{array}$ & $\begin{array}{c}59 \\
(59,60)\end{array}$ \\
\hline
\end{tabular}

NOTE: Ninety-five percent confidence intervals from bootstrapping are shown in parentheses.

\section{ACCOUNTING FOR THE GROWTH OF CREDIT CARD DEBT}

In 1992 total card balances owed by households was nearly $\$ 92$ billion. By 1995 , that figure grew to nearly $\$ 130$ billion, a growth of 41 percent. So what accounted for this growth? Did the increase in the number of households with credit cards affect the growth more than the increase in average balances? Did households in the bottom half of the income distribution affect the growth more or less than those in the top half?

Using the data from the surveys, I can assess the relative importance of those two factors on the increase in debt between 1992 and 1995 by holding one factor constant while changing the other. So the effect of more cardholders equals the change in cardholders times the average credit card debt from the base year. Similarly, the effect of higher indebtedness equals the number of cardholders in the base year times the change in average debt. There is a third term, an interaction term, which accounts for the interaction of new cardholders and higher average balances. Figure 3 shows the relative contributions of the three factors to the growth of credit card balances, and Table 3 shows the growth rate of the various factors between surveys. 


\section{Figure 2 \\ Income Distribution of Credit Card Debt \\ Percent of Total Credit Card Debt}

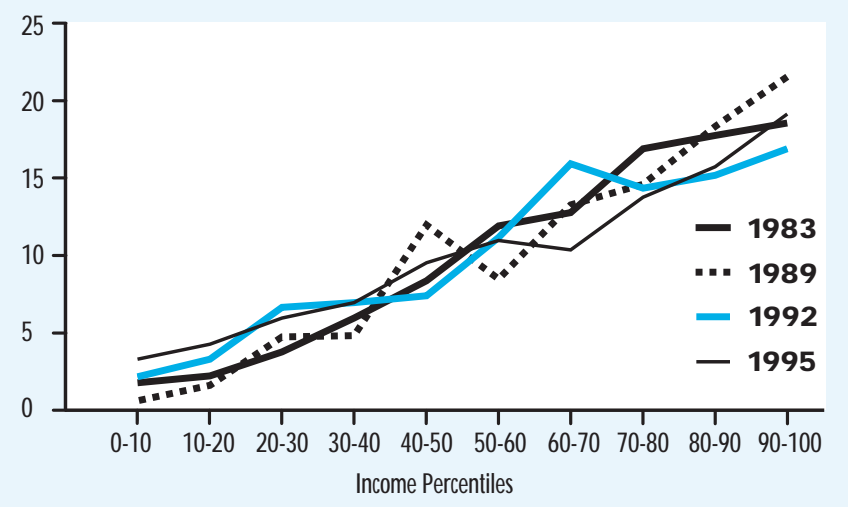

Changes in the number of households with credit cards accounted for little of the increase in total debt. The total number of households with credit cards increased at a 2.4 percent annual rate between 1992 and 1995, nearly twice the growth rate of the number of all households during the time period. This increase in the number of households with credit cards accounted for 17 percent of the growth in credit card debt between 1992 and 1995.

Changes in average balances accounted for the vast majority of the increase in total credit card debt between 1992 and 1995. Average credit debt of all households grew at a 9.6 percent annual rate during those three years, considerably faster than the increase in prices, 2.8 percent annual rate, and household income, 4.9 percent annual rate. ${ }^{8}$ In sum, the increase in average credit card balances accounted for 77 percent of the increase in household credit card debt between 1992 and 1995.

So did lower-income households, those in the bottom half of the income distribution, have much effect on the change in total debt? The data suggest that they did not account for most of the increase in credit card debt,

${ }^{8}$ Kennickell, et al. (1997) estimates that the debt-to-asset ratio for all households was 15.9 percent in 1989, 16.3 percent in 1992, and 16.0 percent in 1995. Lower-income households accounted for 39 percent of the growth between 1992 and 1995; they accounted for 35 percent of the growth between 1989 and 1992 and 25 percent of the growth between 1983 and 1989.

\section{Figure 3}

Accounting for the Growth of Total Credit Card Debt
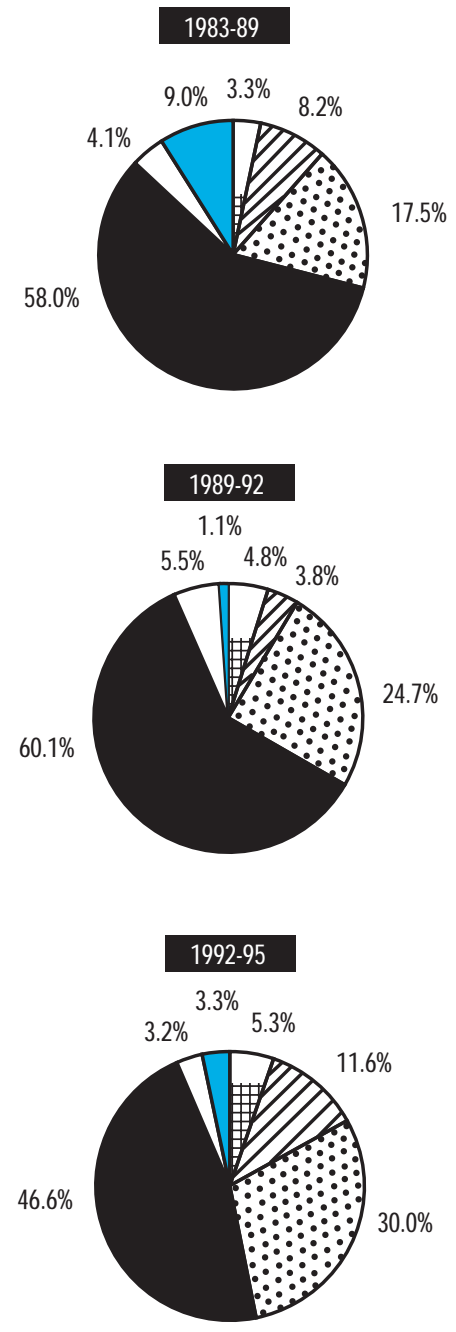

Number of Lower-Income Househ

Vumber of Upper-Income Househ

A Average Balances of Lower-Incor

Average Balances of Upper-Incon

Interaction Term for Lower-Incor 


\section{CONCLUSION}

Household data from the Survey of Consumer Finances from 1995 suggest that increases in credit card debt between 1992 and 1995 are largely attributable to higher average credit card debt per household, not from more households with access to credit cards. Moreover, households in the top half of the income distribution accounted for most of the growth of credit card debt, although lowerincome households increased their access to credit cards and their average debt at faster rates than the total population. Therefore, most of the increase in credit card debt between 1992 and 1995 is attributable to households with previous credit card experience and with above-average incomes.

The survey data also suggest that the changes between 1992 and 1995 reflect a continuing trend rather than a new situation. Lower-income households were more likely to have a credit card in 1995 than in previous survey years, yet the changes are consistent with the pattern established between the other survey years. These households also increased their average balances, but again the growth in their average credit card debt is not notable when compared to previous growth rates.

\section{REFERENCES}

Antoniewicz, Rochelle L. "A Comparison of the Household Sector from the Flow of Funds Accounts and the Sunvey of Consumer Finances," unpublished paper, Board of Govemors of the Federal Reserve System, February 1996

Avery, Robert B., and Gregory E. Elliehausen. "Financial Characteristics of High-Income Families," Federal Reserve Bulletin (March 1986), pp. 163-77. and Glenn B. Canner. "Survey of Consumer

Finances, 1983: A Second Report," Federal Reserve Bulletin (December 1984b), pp. 857-68.

, and . "Survey of Consumer Finances, 1983," Federal Reserve Bulletin (September 1984a), pp. 679-92.

, and Arthur B. Kennickell. "Measuring Wealth with Survey Data: An Evaluation of the 1983 Survey of Consumer Finances," Review of Income and Wealth (December 1988), pp. 339-69.
Kennickell, Arthur B., and Martha Starr-M cCluer. "Changes in Family Finances from 1989 to 1992: Evidence from the Survey of Consumer Finances," Federal Reserve Bulletin (October 1994), pp. 861-82.

, and Annika E. Sunden. "Family Finances in the U.S.: Recent Evidence from the Survey of Consumer Finances," Federal Reserve Bulletin (January 1997), pp. 1-24.

and Janice Shack-Marquez. "Changes in Family Finances from 1983 to 1989: Evidence from the Survey of Consumer Finances," Federal Reserve Bulletin (January 1992), pp. 1-18.

Yoo, Peter S. "Charging Up a Mountain of Debt: Accounting for the Growth of Credit Card Debt," this Review (March/ April 1997), pp. 3-13. 